\title{
Student's Need Analysis for the Development of Chemistry Modules Based Guided Inquiry to Improve Science Process Skill
}

\author{
Arantika, J. ${ }^{1}$, Saputro, S. ${ }^{2}$, Mulyani, S. ${ }^{3}$ \\ ${ }^{1}$ Science Education Student, Faculty of Teacher Training and Education, Sebelas Maret \\ University, Indonesia \\ ${ }^{2,3}$ The Faculty of Teacher Training and Education, Sebelas Maret University, Indonesia \\ Corresponding email: janearantika92@gmail.com
}

\begin{abstract}
Process skills are an important aspect of learning science. Scientific process skills help students to develop creativity in learning. Process skills such as observing, formulating questions, interpreting, experimenting, hypothesizing, applying concepts, and communicating. This study aims to analyze the need for development resources needs of science filled with science process skills. Requirement analysis of the development of teaching materials with the skill of the process of science needs to be done because the textbook is the reference a teacher in the class. The subjects matter of chemistry the study was three senior high schools in Sambas, West Borneo. Needs analysis conducted using a qualitative approach, in terms of needs in classroom learning and content of process skills on teaching materials. Data were collected by interviews and questionnaires were analyzed descriptively. The results showed that as many as 27 percents of students perceive the book used in learning has not yet trained the science process skills. As many as 73 percents of students perceive that they need instructional materials in the form of inquiry-based chemistry modules to improve science process skills. Modules are developed based guided inquiry for having guided inquiry learning stages that can practice students' science process skills.
\end{abstract}

Keywords: module; science process; questionnaire; inquiry

DOI: $10.20961 /$ ijpte.v2i0.19750 


\section{INTRODUCTION}

Education is a process of conscious and planned as an effort to create a meaningful learning process. Through the education process of students trained in order capabilities and potentials to develop optimally realized through meaningful learning in school. Educational reforms and teacher change should be inseparable threads in education, but the challenge to achieving both are complex and therefore continues to require attention in all education systems. Meaningful learning is done to replace the traditional teaching style to memorize processes and concepts (Gabby, Avargil, Herscovitz, \& Dori, 2017). Meaningful learning aims to improve life skills as the essence of the constructivist paradigm. Meaningful learning can improve quality human resources such as critical thinking, collaborative, communication and creativity (innovation) which is ready to compete in the $21^{\text {st }}$ century (Ngurah \& Laksana, 2017).

The most important part of planting concepts in science learning is the student process skills that can be applied. Science process skills are the mental abilities that are used to create knowledge, reflect problems and formulate results (Aydin, 2013). Science process skills that are skills everyone must have in order to use in his or her daily life scientifically literate and improve his or her quality of life (Aktamis \& Ergin, 2008). Armed with the skills it has, an individual can recognize his problems and resolve the problem appropriately.

Science process skills are divided into two groups: basic science process skills and integrated science process skills. Chiappetta and Koballa classify scientific skills as science process skills based (observing, measuring, inferring, classifying, predicting, communication) and integrated science process skills (controlling variable, hypothesizing, designing experiments, and interpreting data (Zeidan \& Jayosi, 2015). Skills processes form the core of the investigation, hands-on learning science (Veal, Taylor, \& Rogers, 2009). Another process skill that is integrated process skills, a process which combines the skills of basic process skills for more complex activities by designing the tools used in the experiments and then studying and conducting an investigation on the phenomenon that occurs (Rambuda \& Fraser, 2004).

Science process skills in chemistry learning should be implemented. Students are not only required to learn more about the concepts by rote, but also a learning experience. Teachers should give more experience to students by guiding students to use knowledge of chemistry in everyday life (Aydin \& Cakiroglu, 2017). Teachers can provide a way to find knowledge. Teachers play an important role in teaching science process skills in the classroom through planning and organizing teaching and learning (Amnah et al., 2017). The teacher is not giving the concept of the material to be memorized by students but prepares a learning environment that allows students to build knowledge actively. Things to practiced skills of teachers to students are one of the processes to prepare teaching materials that can be practicing students' skills. Teaching materials such modules can be developed to help teachers (Paulo \& Cruz, 2015).

The module involves conceptual knowledge content and laboratory activities (Winkelmann et al., 2014). The module aims to facilitate student understanding. 
Module emphasized the use of the scientific method of performing an investigation by experimentation (inquiry-based learning) to develop critical thinking and science process skills (Paulo \& Cruz, 2015). Laboratory component aims to encourage the students' ability to design experimental investigation, to verify or reject hypotheses, conduct experiments and the experimental use to solve everyday problems (Hatzikraniotis, Kallery, Molohidis, \& Psillos, 2010). Inquiry learning activities needed to be organized from simple to complex. Thus, the need to do a needs analysis of students to the development of teaching materials laden science process skills to learn skills that are often trained the students in their learning and what students think about the development of the module is the students teaching materials to improve the skills of the process.

\section{METHOD}

This research is a qualitative study conducted in three senior high schools in the district of Sambas, West Kalimantan, Indonesia. The subjects were students of class XII. Samples were randomly selected from 15 students of class XII. Data was collected using a questionnaire and interview sheet. The questionnaire designed to know the learning conditions and learning resources that students use during learning as ways of learning that are applied to the teacher learning. Interview to confirm the results of questionnaires that have been answered. Several statements from the questionnaire were statement developed by the researcher himself. The statement developed by researchers relates to the application of process skills in teaching materials and types of teaching materials that are expected to help teachers trained students' process skills. The questionnaire is divided into three groups of questions: students' opinions about teaching material, student opinion about the content of science process skills in textbooks and student opinions about the expected teaching module

\section{RESULT}

Table 1. Student opinion about teaching material

\begin{tabular}{|c|c|c|}
\hline \multirow{2}{*}{ QUESTIONNAIRE } & \multicolumn{2}{|c|}{ ANSWER (\%) } \\
\hline & YES & $\mathrm{NO}$ \\
\hline Do you use other teaching materials other than textbooks or worksheets? & 33 & 67 \\
\hline $\begin{array}{l}\text { Do you feel there are limitations on the use of teaching materials? For } \\
\text { example, the completeness of the material, format, technical explanations, } \\
\text { see the design, color display, and more? }\end{array}$ & 53 & 47 \\
\hline \multicolumn{3}{|c|}{ Table 2. Student opinion about the content of science process skills in textbooks } \\
\hline \multirow{2}{*}{ QUESTIONNAIRE } & \multicolumn{2}{|c|}{ ANSWER (\%) } \\
\hline & YES & $\mathrm{NO}$ \\
\hline $\begin{array}{l}\text { Do the handbook use already to train you to observe to identify problems, } \\
\text { events or facts? }\end{array}$ & 13 & 87 \\
\hline Do the handbook use that already to formulate hypotheses? & 0 & 100 \\
\hline Do the handbook use already train you to collect the data? & 7 & \\
\hline Do the handbook use already practicing to analyzing data/information? & 0 & 100 \\
\hline
\end{tabular}




\begin{tabular}{lcc}
\hline Do the handbook use already practicing you to plan an experiment? & 0 & 100 \\
\hline $\begin{array}{l}\text { Do the handbook use already train you to prove the hypothesis through } \\
\text { experiments and theory? }\end{array}$ & 7 & 93 \\
\hline $\begin{array}{l}\text { Do the handbook use already train you to communicate the results of an } \\
\text { experiment in a laboratory? }\end{array}$ & 27 & 73 \\
\hline
\end{tabular}

\section{DISCUSSION}

Based on Table 1, it is known that the textbooks used by students still have a deficiency in terms of material completeness, applicative examples, picture or illustrations that can help students understand the material. This is relevant to the results of student interviews for the teaching materials used. Students revealed that used book contains more exposure concepts and exercises. Laboratory activities are one of the learning activities that can help students practicing skills but in some books not many that show activity laboratory to improve student's skills. Student wants a subject textbook resource that is easy to be understood, in the form of a summary that can attract students' interest, and are equipped with supporting pictures, and contains the latest findings related to learning materials. Learning sources used for this study is less interesting because most of the books that are used to wear the language difficult to understand.

Based on Table 2 explained about skills that can be practiced to students in learning. It is relevant to students' interviews with student stating that the material which they have received more often to hear an explanation from the teacher and do exercise. Learning process, as well as books used by students, are not trained hypothesized including in experimental. Collecting data shown in practicum book reveals the process of data collection is never done, just on lab activities that are sometimes instructed by teachers. Especially in planning experiment, directly given purpose, tool material and work step on the books without asking the students to decide. The teacher tried to use learning methods such as group discussions. For learning activities in the laboratory, often performed on certain material such as thermochemical for exothermic reactions and endothermic reactions, enthalpy determination by the calorimeter. Experimental activities carried out by experiment activity in the teacher handbook. Students just do the experiment in the laboratory and instructed to conclude the conclusion of practicum reports.

Based on table 3 are related to the development of modules for students. Most of the students say that guided inquiry module can help them to understand chemistry. Inquiry-based module development is one approach to introduce innovative inquiry-oriented instruction in a conventional classroom. Modules can be used as teaching materials or media for effective learning. The module is a complete teaching unit designed for use learners (Smaldino, Lowther, \& Russel, 2011). In addition to making learning effective and efficient, the module can also be used independently or with the guidance of teachers. The role of the module as a teaching material, in this case, the information provider of basic material for the modules presented a variety of subject matters that could be developed is presented with illustrations or pictures communicative. The module involves 
conceptual knowledge content and laboratory activities. The module aims to facilitate student understanding. Laboratory component aims to encourage the students' ability to design experimental investigation, to verify or reject hypotheses, conduct experiments and the experimental use to solve everyday problems (Hatzikraniotis et al., 2010)

According to Kruea-In and Thongperm (2014), teachers can conduct science process skills integration by stages starting from the observation of the surrounding environment to begin the process of thinking and analyzing skills of students. In the next phase, the students will be guided to a higher stage. Some teachers can focus on the process of identifying the variables and formulate the problem in accordance with the setting place of learning both in the classroom, laboratory, during a demonstration and discussion. Integrating skills in the learning process can be done by doing the most basic skills that observing skills then proceed to other skills gradually. The integration in this study was conducted during the discussions learning, as well as activities in the laboratory using guided inquiry. Inquiry learning activities need to be organized from simple to complex. Investigations using scientific principles and concepts for interpreting the data, it might be more effective to reduce the guidance of time to make students familiar (Hsu et al., 2016).

Constructivist learning model that can be integrated into the students' books to practicing student's science process skills. Studies in Turkey reveal that learning process on the basis of constructivism is the way to develop higher cognitive skills such as skills process (Aydin, 2013). One of the lessons that can be applied is an inquiry. The inquiry is most often used in science learning activities for improving the conceptual understanding and students' science process skills (Lati, Supasorn, \& Promarak, 2012). Inquiry learning students trained to conduct experiments that are mental processes: to observe, to formulate the problem, create and test hypotheses, designing experiments, conducting experiments, collecting data onto experiments and analyse data and draw conclusions and communicate the results of the experiment results both verbally and in writing (Hatzikraniotis et al., 2010). The student involved in the investigation that gave them the opportunity to develop scientific skills and actively building concepts.

Many studies show the effectiveness of the use of relevant inquiry learning to improve students' science process skills, such states using a model guided inquiry showed increased student content knowledge and skills development process of observation, asking questions, and communicate (Strom, 2012). Aktamis and Yenice research shows that students who use the application of science process skills better than the students learn to use techniques that are usually done in the classroom (Aktamiş \& Yenice, 2010).

\section{CONCLUSION}

Teaching materials used in teaching students not maximized practicing science process skills of students, it is necessary to develop teaching materials in the form of modules. Modules are chosen because it can facilitate students to learn, both by educators and independently. The module is a packaged teaching material as a 
whole and schematically. Modules are developed based guided inquiry for having guided inquiry learning stages that can practicing students' science process skills.

\section{REFERENCES}

Aktamis, H., \& Ergin, O. (2008). The Effect of Scientific Process Skills Education on Students' Scientific Creativity, Science Attitudes and Academic Achievements. Asia Pacific Forum on Science Learning and Teaching, 9(1), 21. Retrieved

from http://search.proquest.com/docview/61875613?accountid=14719

Aktamiş, H., \& Yenice, N. (2010). Determination of The Science Process Skills and Critical Thinking Skill Levels. Procedia - Social and Behavioral Sciences, 2(2), 3282-3288. https://doi.org/10.1016/j.sbspro.2010.03.502

Amnah, R., Rauf, A., Rasul, M. S., Mansor, A. N., Othman, Z., \& Lyndon, N. (2017). Inculcation of Science Process Skills in a Science Classroom, 9(8), 47-57. https://doi.org/10.5539/ass.v9n8p47

Aydin, A. (2013). Representation of Science Process Skills in the Chemistry Curricular for Grades 10, 11 and 12. International Journal of Education and Practice, 1(5), 51-63. Retrieved from http://www.pakinsight.com/journals/IJEP.htm\%0AREPRESENTATION

Aydin, G. C., \& Cakiroglu, J. (2017). Learner Characteristics and Understanding Nature of Science. Science and Education, 26(7-9), 919-951. https://doi.org/https://doi.org/10.1007/s11191-017-9939-6

Gabby, S., Avargil, S., Herscovitz, O., \& Dori, Y. J. (2017). The Case of Middle and High School Chemistry Teachers Implementing Technology: Using The Concerns-based Adoption Model to Assess Change Processes. Chem. Educ. Res. Pract., 18, 214-232. https://doi.org/10.1039/C6RP00193A

Hatzikraniotis, E., Kallery, M., Molohidis, A., \& Psillos, D. (2010). Students' Design of Experiments: An Inquiry Module on The Conduction of Heat. Physics Education, 45, 335-344. https://doi.org/10.1088/0031-9120/45/4/002

Hsu, Y.-S., Fang, S.-C., Zhang, W.-X., Wu, H.-K., Wu, P.-H., \& Hwang, F.-K. (2016). Identifying Effective Design Features of Technology-Infused Inquiry Learning Modules: A Two-Year Study of Students' Inquiry Abilities. Journal of Educational Technology \& Society, 19(2), 228-244.

Kruea-In, N., \& Thongperm, O. (2014). Teaching of Science Process Skills in Thai Contexts: Status, Supports and Obstacles. Procedia - Social and Behavioral Sciences, 141, 1324-1329. https://doi.org/10.1016/j.sbspro.2014.05.228

Lati, W., Supasorn, S., \& Promarak, V. (2012). Enhancement of Learning Achievement and Integrated Science Process Skills Using Science Inquiry Learning Activities of Chemical Reaction Rates. Procedia - Social and Behavioral Sciences, 46 , 4471-4475. https://doi.org/10.1016/j.sbspro.2012.06.279 
Ngurah, D., \& Laksana, L. (2017). The Effectiveness of Inquiry-Based Learning for Natural Science Learning In Elementary. Journal of Education Technology, 1, 1-5.

Paulo, J., \& Cruz, C. (2015). Development of an Experimental Science Module to Improve Middle School Students ' Integrated Science Process Skills. DLSU Research Congress 2015, 3, 1-6.

Rambuda, A. M., \& Fraser, W. J. (2004). Perceptions of Teachers of The Application of Science Process Skills in The Teaching of Geography in Secondary Schools in The Free State Province. South African Journal of Education, 24(1), 10-17. Retrieved from http://www.ajol.info/index.php/saje/article/view/24960/20645

Smaldino, S. E., Lowther, D. L., \& Russel, J. D. (2011). Instructional Technology and Media For Learning. Jakarta: Kencana Prenada Media.

Strom, R. K. (2012). Using Guided Inquiry To Improve Process Skills and Content Knowledge in Primary Science. Bozeman, Montana.

Veal, W. R., Taylor, D., \& Rogers, A. L. (2009). Using Self-Reflection to Increase Science Process Skills in The General Chemistry Laboratory. Journal of Chemical Education, 86(3), 393-398. https://doi.org/10.1021/ed086p393

Winkelmann, K., Baloga, M., Marcinkowski, T., Giannoulis, C., Anquandah, G., \& Cohen, P. (2014). Improving Students' Inquiry Skills and Self-Efficacy through Research-Inspired Modules in the General Chemistry Laboratory. Journal of Chemical Education. https://doi.org/10.1021/ed500218d

Zeidan, A. H., \& Jayosi, M. R. (2015). Science Process Skills and Attitudes toward Science among Palestinian Secondary School Students. World Journal of Education, 5(1), 13-24. https://doi.org/10.5430/wje.v5n1p13 
International Journal of Pedagogy and Teacher Education (IJPTE) (Vol. 2 | Focus Issue-January 2018) 